\title{
Toplumsal Cinsiyete Duyarlı Afet Risk Yönetimi
}

\author{
Nilgün OKAY ${ }^{12}$ ve İpek ILKKARACAN ${ }^{3}$
}

Öz

Afete dirençli toplumlar için afet risk yönetiminin yaygınlaştırılmasını gerektirmektedir. Toplumda mevcut olan sosyal zarargörebilirlikler* (kırılganlıklar) bir afet durumunda müdahaleyi daha karmaşık hale getirmekte, iyileştirmeyi daha da zorlaştırmaktadır. Toplumun bireylere kadın veya erkek olarak yüklediği sosyokültürel roller ve sorumluluklar (toplumsal cinsiyet) bu kırılganlıkları arttırmakta afet risklerini daha da yönetilemez hale getirmektedir. Kadınları afetlerde mağdur ve riskli gruplardan kabul eden genel yaklaşım bulunmaktadır. Buna karşılık, toplumsal cinsiyete dayalı kapasite ve yeteneklerini geliştirmeyi amaçlayan yaklaşımların daha başarılı olduğu saptanmıştır. Bu makalede afet yönetiminin zarar azaltma, hazırlık ve müdahale evrelerinde yapılan planlamaların toplumsal cinsiyet bakımından yeniden gözden geçirilmesi, toplumsal cinsiyet duyarlığının geliştirilmesine yönelik stratejik planlama önerileri tartışılmaktadır.

Anahtar Kelimeler: toplumsal cinsiyet, zarargörebilirlik, kapasite, dirençlilik, afet risk yönetimi

\section{Gender Sensitive Disaster Risk Management}

\begin{abstract}
Studies on disaster resilience point out the necessity of participation of all parts of communities in disaster management. Lessons from previous disasters indicate that existing social vulnerabilities based on gender roles are reducing local disaster resilience and preparedness capacities. Strategies based on gender-sensitive disaster mitigation planning are more successful to reduce all vulnerabilities. During the disaster mitigation and preparedness stages, a more proactive and gender based risk management framework helps to recognize more women participating and improve capacities, as well as encourage gender equality and empower women. Gender-sensitive approach should be integrated into the disaster risk management and women should be given equal place in planning. Designing gender-sensitive planning is a right strategy for improving disaster capacity and resilience. During the planning processes, there is an urgent need for raising awareness, and train the trainers and practitioners in the emergency and disaster management field, as well as policy makers in all levels.
\end{abstract}

Keywords: gender, vulnerability, capacity, resilience, disaster risk management

\footnotetext{
${ }^{1}$ Prof. Dr., ITÜ Afet Yönetimi Merkezi

2 ITÜ BMT KAUM Kadın Araştırmaları Merkezi

${ }^{3}$ Prof. Dr., ITÜ İşletme Fakültesi

*ilgili yazar / Corresponding author: okayn@itu.edu.tr

Gönderim Tarihi: 05.06.2018

Kabul Tarihi: 28.06.2018
} 


\section{Giriş}

Afet risklerinin azaltılmasında, hazırlık ve müdahalede mevcut yaklaşımlar hala sorunlarla karşı karşıyadır. Bu sorunlardan belki de en önemlisi, afet yönetiminin her aşamasında olduğu gibi, hazırlıkta da halkın katılımcılığının yeteri kadar sağlanamamasıdır. Bu nedenle, halkın büyük bir kısmının bu süreçlerde yer alamaması, afete dirençliliğini de azaltmaktadır (Okay ve diğ. 2016; Varol ve Kırıkkaya 2017; Okay 2018). Dünyada özellikle kadınlar ulusal ve yerel düzeyde yapılan afet yönetimi planları ve organizasyonlarında yer almamaktadır (Reyes 2002; Odabaşı 2010). Türkiye'de AFAD Ulusal Deprem Stratejisi ve Eylem Planı (UDSEP 2023), Türkiye Afet Müdahale Planı (TAMP) ve iSMEP Afet Risk Azaltma çalışmaları ile afete dirençlilik bakımından önemli ilerlemeler kaydedilmiştir. Belirlenen bu yol haritası, kadının katılımı ve toplumsal cinsiyet duyarlıı̆ı̆ bakımından yetersizdir (İnal ve diğ. 2016). Buna karşın, Türkiye'nin de katıldığı Sendai Afet Risk Azaltma Çerçevesi (2015-2030) kapsamında alınan kararlarda, toplumun zarargörebilirliğinin azaltılması, afet yönetimi süreçlerinin her aşamasında "öncelikle de kadınların katılımının arttırılması hedeflenmiştir (UNISDR 2015). Bu uluslarası kararlarla tüm politika ve uygulamalarda kadının aktif katılımının sağlanması, yerel organizasyonlarda kadın liderliğinin desteklenmesi amaçlanmaktadır. Bu yaklaşım, aynı zamanda kadın yoksulluğunun ve kırılganlığının azaltılmasını, yani sosyoekonomik güçlendirilmesini de sağlamaktadır (UNISDR 2015). Bu bağlamda, zarar azaltma, hazırlık, müdahale, iyileştirme ve yeniden yapılandırma planlama çalışmalarının toplumsal cinsiyete duyarlı şekilde düzenlenmelidir (UNISDR 2017).

Sosyo-ekonomik eşitsizliklerden dolayı, homojen gruplardan oluşamayan toplumlar (Tierney 2007; Ecevit 2011), afetlere karşı diğerlerine göre daha kırılgan olurken afetlerin etkileri de toplumun sosyal özelliklerine göre değişmektedir. Toplumun sosyal ağları, vatandaşlık statüsü, etnik köken, sosyal güvenlik, dil, din, medeni durum ve yaş, dış görünüş, sağlık, beslenme, yönetime katılım, gelir ve istihdam eksikliği, zenginlik ve yaşam kalitesi ve hatta doğum yeri gibi faktörlerin hepsi birden kırılganlığa etki etmektedir. Toplumun okuma yazma oranı, bilgi ve becerilerine bağlı bu kırılganlıklar değişirken, eğitim, sağlık ve gelir kaynaklarına erişimde bu kırılganlıklar ile doğrudan ilişkilidir. Kııılganlıklar arttığında toplumu tehdit eden tehlikelerin afete dönüşme riski de büyümektedir. Bu nedenle, toplumun kırılganlıklarının artmasından dolayı afetler gelişmeyi yavaşlatmakta, kalkınmayı durdurmaktadır.

Türkiye'de nüfusun yaklaşık yarısı olan, 40 milyon kadının nerdeyse tamamı $(\% 92,6)$ kentlerde yaşamaktadır (TÜIK 2017). Birleşmiş Milletler Toplumsal Cinsiyet Göstergeleri Minimum Gösterge Seti'nde yayımlanan verilere göre Türkiye'de kadının ekonomiye katıım oranın \%32,5 olduğu belirtilmektedir. Eğitim almayan, istihdama katılmayan ve geliri bulunmayan kadın (\%24,2 kadarı), düşük ücretli, kayıt dışı işlerde ve sigortasız çalışmaktadır. Kalkınma Programı İnsani Gelişim ile Dünya Ekonomik Forumu (2016) raporlarında, Türkiye'nin ekonomisinin gelişmesine rağmen kadının ekonomiye katılımının az olması, 144 ülke arasında son on senede 130. sıraya düştüğü bildirilmektedir (KAGIDER 2018). Zaten sosyal baskı altında yaşayan kadınlar haklarından yararlanamadıkları gibi, yoksulluk kadınlaşmakta, daha fazla incinebilir ve zarargörebilir duruma düşmektedirler (İlkkaracan 2008; Hattatoğlu 2011). Bu durumda eğitim olanaklarından yeterince yararlanamadıkları için işgücü kapasitelerini kullanamamakta ve ekonomik anlamda da birey olarak kendi yaşamlarını kuramamaktadırlar (Sancar 2011). Bunun yanısıra, Ecevit (2011)'in de belirttiği gibi, Türkiye'nin kültürel farklılıkları ve dinamik yapısı da, olası bir afetin etkilerinin yüksek olmasına neden olacaktır. 
Toplumun kadın ve erkeğe yüklediği farklı sorumluluklardan (toplumsal cinsiyet) dolayı ortaya çıkan sosyal sorunlar, kırılganlığa etki eden en önemli nedenlerdendir. Toplumsal cinsiyete dayalı eşitlik (gender equality) ve insan haklarının (gender equity) yetersizliği bakımından bireylerin fırsat eşitsizliğine ve ayrımcılığa maruz kalması, afetlerin karmaşık hale gelmesine ve etkilerinin daha da artmasına neden olmaktadır. Mevcut cinsiyet eşitsizlikleri nedeniyle sosyoekonomik bağımlılığının artması, kadınları yüksek risk grubuna düşürmektedir. Bu bakımdan, özellikle de afetlerde kadınlar kurban, mağdur ve riskli gruplardan kabul eden yaygın bir anlayış benimsenmiştir. Örneğin, sivil toplum kuruluşları tarafından sürdürülen afet hazırlık çalışmalarında kadınların mevcut kırılganlığının belirlenmesi üzerine odaklanmaktadır.

\subsection{Kırılganlıktan Kapasiteye}

Toplumsal cinsiyete dayalı değişen sosyal özellikler, halkın hazırlık ve müdahale kapasitelerini etkilemektedir. Buna göre, bir afet durumunda kadın ve erkeğin verdiği tepki ve afetle başa çıkma kapasitesi farklılık gösterecektir. Bu yüzden sahip oldukları sosyal yapı gereği kadınların yerel afet yönetimi süreçlerine katılmaları, afete hazırlık için büyük önem kazanmaktadır. Yapılan çalışmalarda, afet öncesinde kadınların, erkeklere göre afete hazırlığı ile ilgili yerel faaliyetlere daha fazla ilgili oldukları bildirilmektedir (Pincha 2008; UNDP 2010; Okay ve diğ. 2014). Kadınların geleneksel rollerinden kaynaklanan sosyokültürel kapasiteleri, bakım becerileri ve sosyal ağları, afet yönetiminde önemli bir kaynak olarak değerlendirilebilir (Enarson 2012). Kadınların afetlerde hayatta kalma mücadelesinde ve iyileşmeyle başa çıkmada erkeklere oranla daha çabuk organize oldukları saptanmıştır (Ariyabandu ve Wickramasinghe 2003). Bir mahallede afet öncesi kadın gönüllü grupları gibi güçlü sosyal yapının mevcut olması, afetlerde müdahaleyi kolaylaştırdığı, afet sonrasında da halkın kendi kaynaklarıyla daha çabuk iyileşme sağlandığı bildirilmektedir (Takeuchi ve diğ. 2012). Kadınların savaşlarda hemşirelik yaptıkları, afetlerde gönüllü olarak yardım dağıtma, temizlik ve geçici barınma yerlerinin hazırlanmasında görevler aldığı bilinmektedir. Bu bakımdan, afet öncesinde hazırlık faaliyetlerinde, afet sırasında kurtarma operasyonları da dahil olmak üzere, kadınların mahalle çalışmalarında destekleyici rollerinden yararlanılabilir. Dolayısıyla, kadınlar çaresiz, savunmasız, kurban değil, becerileri ve güçlü yönleriyle afetlerle başa çıkma kapasitesine sahiptir (Ferris 2012; El Masri ve diğ. 2013).

\section{Toplumsal Cinsiyet Ve Afet Risk Yönetimi}

Halkın katıııı afet yönetiminin başarısını etkilemektedir (Reyes, 2002). Bu başarı özellikle, risk azaltma planlama ve programlarının halkın tüm kesimleri tarafından sahiplenmesi ile sağlanabilir. Pandey ve Okazaki (2008) tarafından, afet riski altındaki yerleşimlerde pek çok uygulamanın sürdürülebilir hale gelemediği ve bunun sağlanması için halkın katılımının gerekliliği vurgulanmaktadır. Bu bağlamda, sorunun üstesinden gelebilecek yaklaşım, katıımcı, toplumsal cinsiyete duyarlı kapasitelere odaklanan bir afet risk yönetimi şeklinde olmalıdır. Saha çalışmaları ise, kadınların kapasitelerini değerlendiren, daha proaktif, katıımcı bir afet risk yönetiminin başarılı olacağını göstermektedir (Hemachandra ve diğ. 2018). Bu anlayışın, tüm sektörlere ve süreçlere anaakımlaştırılmasının teşvik edilmesi ve yaygınlaştırılması duyarlı bir strateji olacaktır (Fordham 2008; Pincha 2008; Enarson 2012).

Toplumun yarısını oluşturan kadınların afet yönetiminin zarar azaltma ve hazırlık planlama, karar alma ve uygulama süreçlerinde yer alabilmeleri öncelikle yasal bir haktır. Bu katılım yerel, ulusal, uluslararası politikalarla kadın yoksulluğunun ve toplumsal cinsiyet eşitsizliklerinin azaltılmasını sağlayacak, sosyal değişim fırsatı da yaratacaktır. Kadınların

toplumdaki cinsiyet eşitsizliğinden kaynaklanan sosyoekonomik kırılganlıklarının 
azaltılmasıyla riskler de azaltacaktır; dolayısıyla da kapasitelerini kullanılabilmeleri ile afetlere dirençlilik gelişecektir (Fordham 2008; Pandey ve Okazaki 2008).

\subsection{Mevcut Durum Değerlendirme}

Afetlerde sosyal kırılganlıkları azaltırken toplumsal cinsiyet perspektifinde değerlendirmek, kapasiteleri geliştirmeye ve katılımcılığa odaklanmak afet risk yönetiminde henüz yeterince uygulanmamaktadır. Toplumun sosyoekonomik zarargörebilirlikleri ve sosyokültürel kırılganlıklarının yanısıra kapasitelerinin değerlendirilmeden geliştirilen kalkınma plan, yatırım ve politikaları afete dirençlilikte yetersiz kalmaktadır (Odabaş 2010). Genellikle değerlendirme yaparken ölü ve yaralı sayısı, hasarlı yapı dağılımı, ya da üretim kayıplarından bahsedilirken fiziksel zarargörebilirlik göz önüne alınmaktadır. Afetlerin sadece doğal tehlike ve risklerden ibaret ele alınması ve sosyal süreçlerden soyutlanması, afet risk yönetiminin uygulamada da kısıtlı kalmasına yol açmaktadır. Böylece, riskleri azaltmak yerine yeni riskler ortaya çıkmaktadır (Wisner ve Levell 2017).

Sosyokültürel ve sosyoekonomik kırılganlıklar olası bir afette ortaya çıkacak zararın büyüklüğü, müdahale ve iyileşmenin nasıl olacağının bir göstergesidir. Yerelin kendine özgü kültürel ve politik yapısından kaynaklanan özel durumlarının da afet yönetimi süreçlerine anaakımlaştırılması gereklidir. Kapsamlı afet risklerinin tanımlanması ve değerlendirilmesi ve alınacak zarar azaltma önlemleri toplumsal cinsiyete bağlı kırılganlıklar bakımından yeniden tasarlanmalıdır (Enarson 2012; Pandey ve Okazaki 2008). Bu bakımdan, yerelin afetlerden önce sosyokültürel ve sosyoekonomik özelliklerinin ortaya konulması gerekir (Yönder ve diğ. 2005; Özceylan 2012). Afet risk azaltma planlamasına başlarken mevcut kırılganlık ve kapasitelerin toplumsal cinsiyete göre kapsamlı değerlendirilmesi yapılmalıdır. Bu ölçme ve değerlendirmeler, kadın ve erkeklerin bilgi, algı ve kapasitelerini, maruz kaldıkları farklı risklerin farklı etki derecelerinin de belirlenmesini sağlayacaktır. Toplumun sosyal özelliklerinin tespit edilmesinde ölçülebilen, değerlendirilebilen göstergeler (istihdam ve gelir kaynakları, yaşam kalitesi, eğitim, sağlık, sosyal ağlar) toplumsal cinsiyet analizleri (gender analysis) adı altında yapılan bu çalışmalar, afet sonrasında iyileştirme ve yeniden yapılanma aşamasında yaygınca kullanılmaktadır (WBI 2012; GFDRR 2014; UNDP 2010, 2017). Ortaya çıkarılan bu göstergelerin dağılımına göre, riskler değerlendirilerek risk yönetimi araçları (sakınma, önleme, azaltma, risk transferi, risk iletişimi) ile zarar azaltma planlamasında politikaların geliştirilmesini, uygulanmasını, izlenmesini ve gerekli değişikliklerin yapılmasına dayalı stratejileri geliştirilebilir (Okay 2018). Kadınların eğitim, istihdam, yönetime katılımının yanısıra kadına yönelik şiddet, sosyal güvenlik oranlarını tespit eden ve eşitsizlikleri ortaya koyan değerlendirmeler yapılmakta; bunlara karşı stratejik çözümler geliştirilmektedir. Bu çalışmalar risk yönetimi araçlarının önceliklerinin belirlenmesinde ve zarar azaltma planının geliştirilmesinde kullanılması yararlı olacaktır.

\subsection{Sorunlar ve Planlama}

Dünyanın birçok ülkesinde kadınlar afetlerde tahliye sorunları yaşamaktadır. Bunun nedeni, erken uyarı sistemlerinin ve tahliye planlarının kolay anlaşılır olmaması ve benimsenememesidir. Afet anında evde yalnız olan kadınların kaçış yollarını bilmemeleri, afet koordinasyonundaki görevlilerin erkek olması bile kadınların tahliye olamasını zorlaştırmaktadır (Ariyabandu ve Wickramasinghe 2003; Pincha 2008; Juran 2012). Bu durumda, afetlerde yaşamlarını kaybeden kız çocuk, hamile, hasta, yaşlı, azınlık, göçmen, mülteci kadın ve LGBT bireylerin ölüm oranı fazla olmaktadır (Pincha 2008; Odabaşı 2010; Petek 2011). 
Afet sonrasında yaşamın sosyal anlamda zor ve sıkıntılı olduğu, geçici barınma koşullarının iyi olmadığı bir gerçektir (Dedeoğlu 2011; Juran 2012). Örneğin, 2011'deki depremleri sonrasında, Van çadır kentlerinde kadınların yaşam ve hareket özgürlüklerini kısıtlayan durumlar yaşadıkları (tuvaletleri kullanma ve yıkanma yeri nedeniyle gitmeye çekindikleri, hatta engellendikleri) bildirilmektedir (Işık ve diğ. 2015; Açıkalın 2017). Geçici barınma sırasında sağlık hizmetlerinde çalışan doktorların erkek olması, kadınların doktora gitmeye çekinmesine ve sağlık sorunlarının artmasına neden olmaktadır. Çadırda yalnız yaşamaktan çekindikleri için kadınların hasarlı binalarda kalmaya devam ettiği sık gözlenen durumlar olmuştur. Çadır kentlerde gündelik ev işlerini yetersiz, zor şartlarda yürütmek durumunda olan kadınların gelir durumu, sağlık ve yaş faktörlerine bağlı olarak sorunları artmaktadır (Bradshaw 2004). Afet sonrasında ekonomik nedenlerle erkeklerin evden ayrılması, çocuklarıyla yalnız kalmasıyla kadınların güvenlik sorunlarını da arttırmaktadır. Afet sonrasında geçici barınma sorunlarının ağırlaşmasıyla kadına yönelik mevcut fiziki, psikolojik, cinsel ve ekonomik şiddet ve ayrımcılığın artması ile dövülme, cinsel taciz ve tecavüz vakaları sıkça yaşanmaktadır (Phillips ve Morrow 2008; Karancı ve diğ. 2011). Van depreminden sonra bölgede intihar edenler arasında şiddet görmüş kadın oranı oldukça yüksek olduğu bildirilmektedir (Işık ve diğ. 2015).

Kadınların geçici barınma alanlarında daha fazla zaman geçirmeleri, bu alanların tayininde, altyapı tesislerinin (güvenlik, temizlik, suya erişim yolları v.b.) saptanmasında ve tasarımında, kadınların intiyaçlarına, günlük işlerine ve çocuklarının eğitim gereksinimlerine uygun düzenlenmasi, başka bir deyişle, bu alanların kadın gözüyle planlanması önem taşımaktadır (Pincha 2008; Xu ve diğ. 2014). Bu bakımdan afet risk yönetimi kapsamında kadınların da yer aldığı müdahale planlanması daha da önem kazanmaktadır (Xu ve diğ. 2014). Bu süreçte toplumsal cinsiyete duyarlı intiyaçların tespit edilmesi, sosyoekonomik kapasitesinin arttırıımasına yönelik çalışmaların yapılması ve toplumsal cinsiyete duyarlı talimatnamelerin geliştirilmesi gerekmektedir. Yerel halkın sosyal özellikleri ve zarar azaltma kriterleri gözönüne alınarak (Okay 2018), uzundönem-zarar azaltma planlama ve öncelikli stratejiler oluşturulmalıdır.

\subsection{Katılımcılığı ve kapasiteyi arttırmaya yönelik risk iletişimi}

Risk değerlendirmesi sonucu kabul edilebilir riskin halkın tüm kesimleri tarafından doğru algılanmasıyla hazırlık kapasitesinin artması mümkün olacaktır. Bu bağlamda, risk iletişimi, afete hazırlık ve dirençlilikte en önemli araçlardandır. Risk iletişiminin halkın tüm kesimlerine ulaşmada yetersiz kalması, dolayısıyla, afet risk yönetimi süreçlerine katıımını da sınırlamaktadır. Özellikle risk iletişimi çalışmalarının halkın erişiminin kısıtlı olduğu kamusal alanlarda gerçekleştirilmesi, başta kadınlar olmak üzere, yeterli farkındalık ve bilgilenme sağlanamamakta, bu durumda paylaşım ve katkı da azalmaktadır. Eğitim ve bilinçlendirme risk iletişiminin bir parçasıdır; eğitimlerin kadınlara ulaştırılması, toplumun eğitimi demektir (Kağıtçıbaşı 2010). Kadınların zarargörebilirliklerinin azaltılması, kapasitelerinin arttırılması için çift-yönlü risk iletişiminin sağlanması, dolayısıyla afet risk yönetimi süreçlerine katılım ve hazırlık bakımından önemlidir. Bu çalışmaların, sosyal kırılganlığı arttııcı faktörler göz önüne alınarak farklı risk algılarına göre iletişim yöntem ve araçlarının kullanılması gerekmektedir. Bu süreçlerde yerel kadın gönüllü gruplarının yer alması, afetlerle başa çıkmada başarıyı arttırmaktadır (Enarson 2012). Bir mahallede kadın gruplarının olması, afet öncesi güçlü bir sosyal dayanışmayı sağlayacağı için, afete hazırlık kapasitesinin de artmasını sağlayacaktır.

Türkiye'de sivil örgütler tarafından yürütülen kadınların afet kapasitelerinin arttırılmasına yönelik, başarılı örnek çalışmalar yapılmaktadır (Odabaş 2010). Örneğin, 17 Ağustos 1999 depremi sonrasında kurulan Kadınlarla Dayanışma Grubu (KADAV) bölgede afet-sonrası psikolojik iyileştirme ve sosyoekonomik destek projeleriyle kadının güçlenmesine yönelik gönüllü eğitim ve girişimcilik çalışmaları sürdürmüştür (KADAV 2012). Diğer bir oluşum, afet 
bölgesindeki kadınların ev ekonomisi deneyimlerini işgücüne dönüştüren ve gelir getirici faaliyetleri amaçlayan Kadın Emeğini Değerlendirme Vakfı (KEDV) olmuştur. KEDV tarafından ekonomik güçlendirme programları (kadınlara pazarlama alanlarında, mesleki eğitim ve danışmanlık desteği ile kooperatifler kurulması) ve başarılı mikrokredi uygulamaları desteklenmektedir. Bu bağlamda, özellikle İstanbul, Marmara ve Güneydoğu Anadolu'da bazı yerel yönetimler ve mahalli organizasyonların desteği ile çok sayıda kadın ve çocuk merkezleri hizmet vermektedir (Yönder ve diğ. 2005).

Kadınların planlama süreçlerine katılımının sağlanması, sosyoekonomik kapasite güçlendirme eğitimlerinin yanısıra afet eğitimi, acil eylem planlarına yönelik tatbikat ve tahliye eğitimlerinin de verilmesi gerekir. Bu kapsamda, yerel ve gönüllü organizasyonların kadının toplumsal rollerine ve sosyal kapasitesine yönelik verdikleri eğitimlerin genellikle tek yönlü bilgi akışı şeklinde olduğu gözlenmektedir (Takeuchi ve diğ. 2012; Okay ve diğ. 2014; 2016). Sadece riske yönelik tek-yönlü bilgi verilmesi yeterli olmamaktadır. Halkın kapasitesi, intiyaçları ve görüşlerinin anaakımlaştırıldığı bir risk iletişimi yaklaşımı daha başarılı olacaktır. Bu bağlamda, İstanbul'da iSKA tarafından desteklenen Tuzla Illçesi Afet Risk Yönetiminin Geliştirilmesi Projesi kapsamında toplumsal risk yönetimi çalışmaları gerçekleştirilmiştir (Okay ve diğ. 2014). Kızılay, belediye ve üniversite işbirliğinde, temel afet bilinci eğitimleri verilmiştir. Yerel gönüllü kadın grubu ile zarar azaltma planlaması ve risk azaltma stratejileri geliştirilmesinde mahalle risk tespit ve stratejik planlama çalışmaları yürütülmüştür (Şekil 1). Bölgede yapılan bu uygulamalı eğitim, saha ve masa-başı çalışmalarla mahalli riskler değerlendirimiştir. Böylelikle, yerel kadın organizasyonun afetlere karşı sosyal anlamda dirençliliğin sağlanması ve geliştirilmesi için karar verme kapasitelerini arttırmaya yönelik katılımcı planlama çalışmaları gerçekleştirilmiştir (Okay ve diğ. 2014).
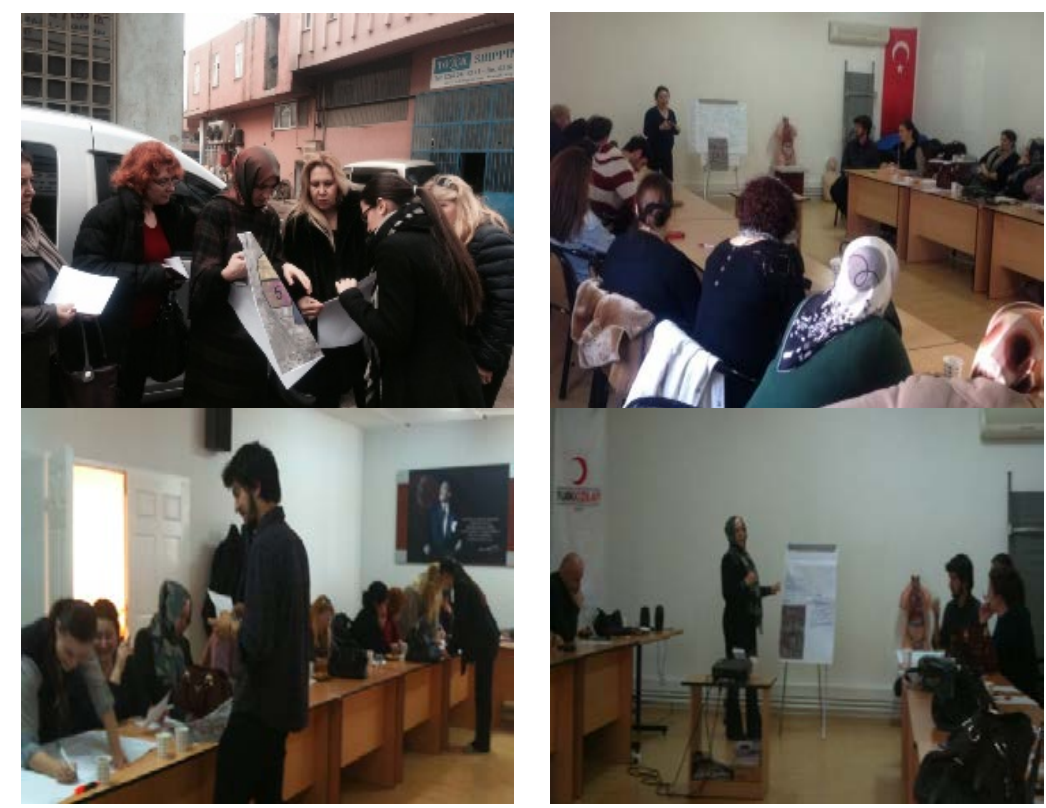

Şekil 1. Tuzla ilçesinde mahalli risk tespit saha ve masa başı çalışmaları (Okay ve diğ. 2014).

Yapılan çalışmalara katılan kadın gönüllülerin afet konusundaki farkındalık ve bilgi düzeylerinden yola çıkarak, afet hazırlıklarının gündelik yaşamdaki yeri ve ileriye dönük risk yönetimi için yapılabilecekleri hususunda bir ölçme ve değerlendirme çalışması yapılmıştır. Katılımcıların verdikleri anket sonuçlarına göre; bir afet sonrasında iletişim, ulaşım, afet eğitimi, dayanıklı bina ve önceden yapılan tatbikatların, sosyal dayanışma, dini inanç ve 
pozitif düşünmenin önemi vurgulanmaktadır (Şekil 2a). Örneğin, afet sonrasında yerel bir organizasyonda görev almak (\%25), ihtiyaçların dağıtımından (\%13), arama kurtarma (\%18), eğitime (\%19) kadar farklı alanlarda gönüllü çalışma istediklerini ifade etmiştirler (Şekil 2b). Ayrıca hastane gibi acil durumla ilgili işlerde kadınların gönüllü olarak görev almak istedikleri belirtilmektedir.

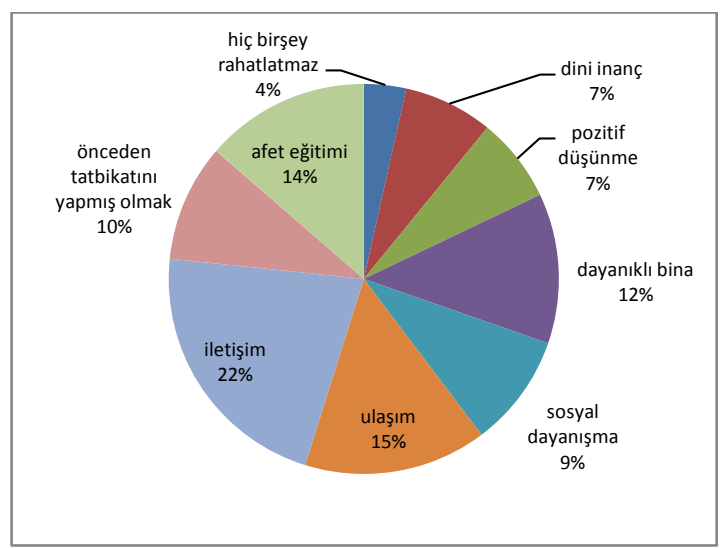

a

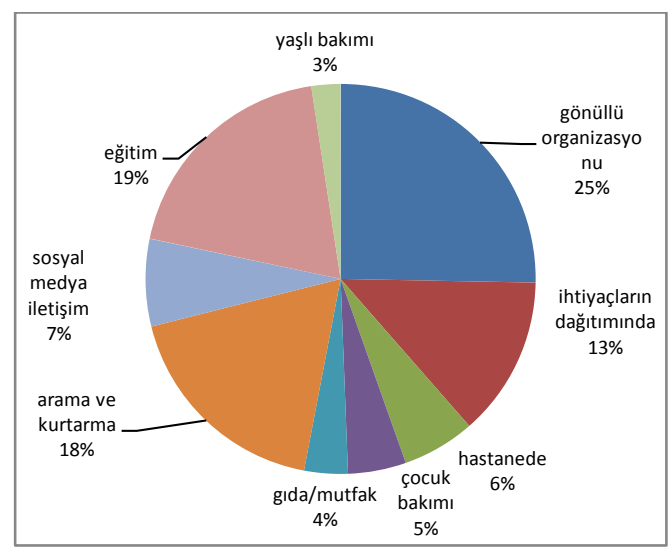

b

Şekil 2. Planlama çalışmalara katılan kadınların afet hazırlığı ve müdahaleye yönelik gönüllülük faaliyetleri hakkında düşünceleri (Okay ve diğ. 2014).

Son olarak, afet sonrası geçici barınma alanlarında görev alacak çalışanların toplumsal cinsiyet yaklaşımlı eğitimlerden geçmesi gerekmektedir. Eğitim içerikleri oluşturulurken çiftyönlü iletişimin geliştirilmesi, toplumsal cinsiyete duyarlı kırılganlık ve kapasitelerinin dikkate alınması sağlanmalıdır. Bu amaçla, Dünya Bankası Enstitüsü tarafından Afet Risk Yönetimi Uzaktan Eğitimi Sertifika programında Toplumsal Cinsiyete dayalı Afet lyileştirme ve Yeniden Yapılandırma kursu 2012 yılında başlatılmıştır (WBI 2012). İnternet üzerinden sunulan bu sertifika kursu Hindistan'ın (NIDM 2016) ve Filipinler'in (EMI 2015) afet ve acil durum yönetimi kurumları tarafından da uyarlanmıştır. Aynı yaklaşımla tasarlanarak, İstanbul Teknik Üniversitesi'nde Afet Yönetimi Yüksek Lisans Programında geliştirilen Toplumsal Cinsiyete Duyarlı Afet Yönetimi dersi de 2013'den beri verilmektedir (Okay ve diğ. 2013).

\section{Tartışma: Planlamaya Yönelik Stratejik Öneriler}

Ülkelere özgü sosyokültürel, siyasi ve kurumsal engellere rağmen kadınların afet yönetime katılımı Sendai Afet Risk Azaltma Çerçevesinin öncelikli hedeflerindendir. Ekonomik gelişmelere rağmen, kadının durumunun iyileştirilmesi sorunlu olmaya devam etmekte, Türkiye toplumsal cinsiyet bakımından dünya indekslerinde giderek en alt sıralara düşmektedir. Toplumsal cinsiyete duyarlı afet risk yönetimi planlama çalışmalarına göre düzenlenen kalkınma politikaları, bu kısır döngüyü aşabilecek çareleri sağlamaktadır. Bu yaklaşımla toplumsal cinsiyet değerlendirme, ulusal ve yerel stratejik çalışmaların olmazsa olmaz bir bileşeni haline gelmelidir. Bu kısımda toplumsal cinsiyet anlayışının afet yönetiminin tüm evrelerine anaakımlaştırıması 10 adımda özetlenmektedir.

1. Afet risk yönetimi halkın tüm kesimlerinin katılması gereken bir süreçtir. Afet olduğunda sadece AFAD veya Kızılay yeterli değildir. Afet öncesinde zarar azaltma ve hazırlıktan herkes sorumlu olmadıkça, afete dirençliliğin sağlanamayacağı bir gerçektir. Kadınların planlamada yer alması temel insan hakları olmasının yanısıra, yerel planlama ve stratejilerde toplumsal cinsiyet eşitliğini sağlayan politikaların daha başarılı olduğu, böylelikle, halkın afetlere direçlilik kazandığı saptanmıştır. 
2. Türkiye'de kadının katıımının sağlanması için başta AFAD olmak üzere resmi kurumlarda, müdahale ve gönüllü ekiplerinde kadın temsiliyetinin arttırılması sağlanmalıdır. Mahalle kadın örgütlenmelerinin yerel yönetimler tarafından desteklenmesi, çok sayıda kadına ulaşılması, sürdürülebilir iletişim ve eşgüdümün kurulması için önemlidir. Bu işbirliği, kadınların kırılganlıklarını azaltmanın ve ihtiyaçlarını karşılamanın ötesinde kapasitelerini geliştirilmesini de kolaylaştıracaktır.

3. Afetlerde kadınları kııılgan kesim olarak tanımlayan eski yaklaşımlar yerine, geleneksel rollerini ve sosyal dayanışma ağlarını kaynak olarak tanımlayan, kapasitelerini göz önüne alan daha proaktif bir yaklaşımla afet risk planlama, talimatname ve stratejilerinin geliştirilmelidir. Bu bağlamda, UDSEP 2023 ve TAMP'ın toplumsal cinsiyet bakımından yeniden gözden geçirilmesi, zarar azaltma, hazırlık, müdahale ve iyileştirme planlama süreçlerine kadın katılımı sağlanmalıdır.

4. Afet risklerinin değerlendirilmesinde toplumun sosyal, ekonomik, kültürel özelliklerini içeren yerel verilere intiyaç vardır. Bu verilerle elde edilen toplumsal cinsiyete duyarlı hassasiyet değerlendirmeleri planlamalarda kullanılmalıdır. Kırılganlıkların veya zarargörebilirliklerin, kapasite ve kaynakların değerlendirilmesinde, afet öncesinde sürdürülecek geliştirme, güçlendirme ve uzun dönem yapılandırma ve kalkınmaya yönelik projeleri yönlendirmesi bakımından gereklidir. Bu aşamada kadın ve erkeklerin kapasitelerinin arttırılması için farklı destek mekanizmalarının oluşturulması, yerel kadın gruplarının risk değerlendirme sürecindeyer alması önerilmektedir.

5. Toplumsal cinsiyete duyarlı sosyal göstergelerin kullanılması ve risk değerlendirmesine katılması ve oluşturan kapasite veri tabanı, afet sonrası hem ihtiyaç tespitini kolaylaştıracak hem de iyileştirme ve yeniden yapılandırma için toplumun her kesimini kapsayacak uzun-dönem zarar azaltma stratejilerini tasarlamak mümkün olacaktır.

6. Müdahale ve yerel gönüllü ekiplerinde özellikle kadın katılımının ve planlamanın her aşamasında kadınların aktif yer almasının sağlanması gerekir. Afet risk yönetiminde toplumsal cinsiyete dayalı sosyo-kültürel kısıtlamaların, toplumsal cinsiyete duyarlı kırılganlıkların risk oluşturduğu, planlama süreçlerinde dikkatle ele alınmalıdır. Planlamada kadınların sadece özel ihtiyaçları değil, hem eşitlik bakımından hem de temel bir insan hakkı olarak kaynaklara erişiminin değerlendirilmesi önemlidir.

7. Risklerin doğru algılanmasında, hazırlık ve müdahale kapasitesinin, kısaca afet dirençliliğinin arttırılmasında risk iletişimi oldukça önemlidir. Kadınların riskler konusunda tek-yönlü, pasif bilgilendirilmesi yerine mahalli risk değerlendirme çalışmaları ile afete duyarııı̆ın arttıııması ve risk azaltma çalışmalarına katılımı sağlanmalıdır. Toplumun sosyal özelliklerine göre değişen farklı, güvenilir iletişimi geliştirecek yöntemlerinin kullanılması teşvik edilmelidir. Çoğunlukla kapalı alanlarda bulunan kadınlara yönelik erken uyarı ve tahliyeye yönelik tercih edebilecek uygulamaların geliştirilmesi, eğitimlerinin yaygınlaştırılması ve yerel kadın kuruluşlarından destek alınması sağlanmalıdır.

8. Müdahale ekiplerinin toplumsal cinsiyet farkındalığının arttırılması gerekir. Eğitimler, afet risk yönetimi sürecinde görevli tüm ADS uzmanlarının (AFAD, Belediye, Emniyet) ve yerel yöneticilerin toplumsal cinsiyet duyarlıığı ve farkındalığının arttırılmasına, bunun için gereken önlemlerin alınabilmesi için planlamanın geliştirilmesine yönelik çalışmalarına başlatılmalıdır. Aynı zamanda STK'larının kadınlara yönelik mevcut hizmetlerinin sınırlı olması ve afet risk azaltma bilgi yetersizliği de göz önüne alınarak eğitmen eğitimlerinin AFAD tarafından akredite olması ve desteklenmesi sağlanmalıdır. Hareket ve çalışma özgürlüklerine engel olan sosyokültürel kısıtlamaların afet kırılganlıklarını ve risklerini arttırdığı yaklaşımının esas alındığı, halkın kültürel bakış açısını değiştirecek eğitim seferberliklerinin başlatılması ülkemizin öncelikli hedeflerindendir.

9. Müdahalenin en sıkıntılı olduğu geçici barınma koşulları ve süreçleri hakkında hem yetkili personelin hem de halkın eğitilmesi gerekmektedir. Toplumsal cinsiyete duyarlı güvenliği sağlayacak, öncelikle şiddete yönelik önlemlerin alınması, hem yerel yönetimin hem de sivil toplum kuruluşlarının (STK)'ların ortak çalışmasını sağlayacak sosyal altyapı 
düzenlemeleri afet öncesi zarar azaltma planlamasında ele alınmalıdır. Toplumsal dayanışma ağlarının çalışır durumda olması (yerel halk kültür merkezleri ve kadın sığınma evlerinin acil durum hizmet altyapısı olarak geliştirilmesi ve etkinliklerle desteklenmesi), yaşamsal hizmetler, kadın sağlığı açısından özel bakım ve 24 saat yetkin tıbbi destek intiyaçları bakımından geçici barınma planlaması yapılmalıdır.

10. Afet sonrasında iyileştirme, toplumsal bir fırsat haline dönüştürülmelidir. Bu yüzden afetlerde sosyoekonomik iyileştirme ve yeniden yapılanma, en az fiziksel yapılara yönelik iyileştirme kadar önemlidir. Uzun-dönem zarar azaltma evresinde iyileştirme ve yeniden yapılanma planlaması yapılırken kadınların kapasitelerini geliştirecek programlara (örneğin, kadın girişimciliğe teşvik veren mikrokredi eğitim ve proje çalışmaları gibi) erişiminin ve bu planlama çalışmalarında kadının aktif olarak katıımının sürekliliği sağlanmalıdır. 


\section{Kaynaklar}

Açıkalın O. (2017). Deprem Bağlamında Dirayetli Toplumun Neresindeyiz: Yüzyılın Hesabı. Yeni İnsan Yay.138.

Ariyabandu M.M., Wickramasinghe M. (2003). Gender Dimensions in Disaster Management: A Guide for South Africa. Sri Lanka: ITGD South Africa Publication.

Bradshaw S. (2004). Socio-economic Impacts of Natural Disasters: A Gender Analysis https://www.gdnonline.org/sourcebook/chapt/doc_view.php?id=2\&docid=50

Dedeoğlu N. (2011). Van Depremi'nden alınacak dersler. Toplum ve Hekim, 26 (5): 378-382.

Ecevit Y. (2011). Toplumsal Cinsiyet Sosyolojisi ed. Ecevit Y, Karkıner N. (T.C. Anadolu Üniversitesi Yayını, No: 2307, Eskişehir).

El-Masri R., Harvey C., Garwood R. (2013). Shifting Sands: Changing gender roles among refugees in Lebanon. Oxfam, 43.

EMI (2015). The Natural Disaster Risk Management Program, http://emimegacities.org/ndrmp/

Enarson E. (2012). Women Confronting Natural Disaster: from vulnerability to resilience. Lynne Rienner Publ. US. 245s.

Ferris D.E. (2012). Disaster Risk Management: A gender-sensitive approach is a smart approach, in Chapter 4: The Year of Recurring Disasters: A Review of Natural Disasters. 2012 (https://www.brookings.edu/research/reports/2013/03/natural-disaster-review-ferris

Fordham M. (2008). The Place of Gender in Earthquake Vulnerability and Mitigation, 2 Ocak 2009, http://www.iiasa.ac.at/Research/RMS/july2000/Papers/fordham0208.pdf

Hattatoğlu D. (2011). Gender and Labor within the Turkish Context of Local Development in the Era of Globalization, Analyzing Gender, Intersectionality, and Multiple Inequalities: Global, Transnational and Local Contexts'de, E. Ngan-Ling Chow, M. Texler Segal, L. Tan (ed.), Emerald Group Publishing Limited, s.139 - 159.

Hemachandra K., Amaratunga D., Haigh R. (2018). Role of women in disaster risk governance. Procedia Eng., 212: 1187-1194.

İlkkaracan A.İ. (2008). Birleşmiş Milletler CEDAW Sürecinde Sivil Toplum Örgütleri, Türkiye Gölge Raporları, Kadının İnsan Hakları (KiH)-Yeni Çözümler Derneği, İstanbul, 182 s.

İnal E., Erbaydar Paksoy N. (2016). 2012-2023 Ulusal Deprem Stratejisi ve Eylem Planı'nın toplumsal cinsiyet bakış açısı ile incelenmesi. Fe Dergi, Cilt 8, Sayı 1.

IASC (2018). Gender Handbook for Humanitarian

Action. https://interagencystandingcommittee.org/system/files/2018-

iasc_gender_handbook_for_humanitarian_action_eng_0.pdf

Işık Ö., Özer N., Sayın N., Mishal A., Gündoğdu O., Özçep F. (2015). Are women in Turkey both risks and resources in disaster management. Int'I J. Res. Public Health, 12: 5758-5774. 
ITÜ (2001). Zarar Azaltma Yöntemleri El Kitabı, Seval S., Okay N., Ünal Y. (ed.), ITÜ Afet Yönetim Merkezi Yayınları, iтÜ Press, No. 6

Juran L. (2012). The Gendered Nature of Disasters: Women Survivors in Post-Tsunami Tamil Nadu. Indian Journal of Gender Studies.

KADAV (2012). Afetlerde kadın dayanışması. Van Depremi 1 yaşında Gözlem Raporu.

KAGIDER (2018). Bilgi Bankası, http://www.kagider.org/kurumsal/bilgi-bankas\%C4\%B1

Kağıtçıbaşı Ç. (2010). Türkiye'de Kadın ve Eğitim. Türkiye'de Toplumsal Cinsiyet Çalışmaları. Koç Üniv. Yaynl., s. 9-19.

Karancı N., Kalaycıoğlu S., Başbuğ B. B., Özden T. (2011). Tabanlı-Van (23 Ekim 2011) ve Edremit-Van (9 Kasım 2011) ODTÜ Depremleri Inceleme Raporu. Ankara.

KEDV. Kadın Emeğini Değerlendirme Vakfı. http://www.kedv.org.tr/programlar/afete-hazirlik/

NIDM (2016). Gender aspects of Disaster Recovery and Reconstruction, e-learning on Disaster Risk Management, http://www.onlinenidm.gov.in/pages/course_12.php

Odabaş Z.H. (2010). Sürdürülebilir Afet Yönetimi ve Kadın. Ankara Univ., No: 256, 191s.

Okay N., İlkaracan İ., Akalın A. (2013). Toplumsal Cinsiyete Duyarlı Afet Yönetimi Ders Notları, ITÜ Deprem Müh. Afet Yönetimi Enstitüsü.

Okay N., Tezer A., Terzi, F., Akman Pek N. (2014). Afete Duyarlı Yerleşim Planlama Süreçleri ile Yerbilimleri Verilerinin Bütünleştirilmesi ve Tuzla İlçesi İçin Bir Afet Risk Yönetimi Modeli. Tuzla Belediyesi, s. 293.

Okay N., Fandoğlu N., İlkkaracan İ., Akalın A. (2016). Gender sensitive Disaster Management, Mainstreaming and Dissemination. Building Bridges within the Gender and Women's Studies Community in Turkey. GWS Gender Conference Proceedings: 783-788.

Okay N. (2016). Risk Azaltma. Acil Durum ve Afet Yönetimine Giriş'te, M. Kadığlu (ed.), Atatürk Üniversitesi, ISBN:978-975-442-771-4.

Okay N. (2018). Dirençli Kentler için Afet Risk Azaltma. Şehir\&Toplum (10): 117-127.

Özceylan D. (2012). Van Depremi Sonrası Yaşananlar Işığında Sosyal ve Ekonomik Zarar Görebilirlik Çalışmalarının Önemi. Osmangazi Üniv. İiBF Dergisi, Nisan 2012.

Pandey B., Okazaki K. (2008). Community Based Disaster Management: Empowering Communities to Cope with Disaster Risks, http://unpan1.un.org/intradoc/groups/public/documents/un/unpan020698.pdf

Petek A. (2011). Türkiye'deki Toplumsal Cinsiyete Duyarlı Risk/Zarar Azaltma Çalışmaları İçin Öneriler. ITÜ Fen Bilimleri Enstitüsü, YL Tezi, 105s.

Phillips B., Morrow B.H. (2008). Women and Disasters, From Theory to Practice. IRCD Pub. US. 
Pincha C. (2008). Gender sensitive disaster management: A toolkit for practitioners. Mumbai: Earthworm Books.

Reyes R.R. (2002). Gendering responses to El Niño in rural Peru, Gender and Development, 10: 60-69.

Sancar S. (2011). Nermin Abadan Unat'la Söyleşi. Birkaç Arpa Boyu. Koç Üniv. Yaynl. 9, s.26-37.

Takeuchi Y., Xu W., Kajitani Y., Okada N. (2012). Investigating Risk Communication Process for Community's Disaster Reduction with a Framework of "Communicative Survey Method". J. Natural Disaster Sci., 33 (1): 49-58.

Tierney K. (2007). Disasters and Social Vulnerability: Insights From Theory and Research, http://ocw.mit.edu/NR/rdonlyres/Urban-Studies-and-Planning/11-941Spring2005/570C0D2F-414F-47B9-8DCA-F2C6D76289B3/0/tierney_lect7_s.pdf

TUIK (2017). Toplumsal Yapı ve Cinsiyet

İstatistikleri http://www.tuik.gov.tr/PreTablo.do?alt_id=1068

UNDP (2010). Gender and

Disasters http://www.undp.org/content/dam/undp/library/crisis\%20prevention/disaster/7Disas ter\%20Risk\%20Reduction\%20-\%20Gender.pdf

UNISDR (2015). Sendai Framework for Disaster Risk Reduction 2015-2030. Geneva: http://www.unisdr.org/ files/43291_sendaiframeworkfordrren.pdf

UNISDR (2017). How To Make Cities More Resilient. A Handbook For Local Government Leaders. A contribution to the Global Campaign 2010-2020. Making Cities Resilient - "My City is Getting Ready!", 122s.

Xu W., Li Y., Okada N., Takeuchi Y., Kajitani Y., Shi P. (2014). Collaborative modellingbased shelter planning analysis: a case study in Kobe City, Japan. Disasters, 38 (1): 125147.

Varol N., Buluş Kırıkkaya E. (2017). Afetler Karşısında Toplum Dirençliliği. Resilience/Dirençlilik, 1(1): 1-9.

Word Bank Institute (2012). Distance Learning Program in Natural Disaster Risk Management Program in Gender Aspects of Disaster Recovery and Reconstruction. WBI, Washington DC.

Wisner B., Lavell A. (2017). The Next Paradigm Shift: From Disaster Risk Reduction to Resisting Disaster Risk Creation (DRR > RDRC). Dealing with Disasters Conference, Univ. Durham, UK

Yönder A., Akçar Ş., Gopalan P. (2005). Women's Participation in Disaster Relief and Recovery. SEEDS, 22: 1-37. 